\title{
Koniektura „wewnętrznego języka” w filozofii Johanna Gottfrieda Herdera
}

\author{
Rafał Michalski \\ https://orcid.org/0000-0002-9587-5074
}

\begin{abstract}
Artykuł poświęcony jest omówieniu koncepcji niewerbalnej mowy „wewnętrznych słów”, która stanowi istotny element Herderowskiej teorii genezy języka, pomijany zazwyczaj przez badaczy tematu. Najważniejszym elementem zaprezentowanej interpretacji będzie rozróżnienie dwóch aspektów poznawczej funkcji umysłu ucieleśnionego w zmysłowości, którą Herder wprowadza w miejsce klasycznego pojęcia intelektu: Besonnenheit (identyfikującą uwagę), która koduje znaki ikoniczne w podstawie duszy (fundus animae) oraz Besinnung (refleksyjną uwagę), która przekształca znaki utrwalone przez Besonnenheit w wewnętrzne słowa. Identyfikująca uwaga kompensuje wrodzony człowiekowi deficyt instynktów, natomiast refleksyjna uwaga wprowadza do zmysłowości element autorefleksji i tworzy wewnętrzny dialog duszy samej z sobą, na podłożu którego powstają pierwsze procesy myślowe i język fonetyczny.
\end{abstract}

Słowa kluczowe: język, Johann Gottfried Herder, poznanie zmysłowe, wyobraźnia, fundus animae, identyfikująca uwaga, refleksyjna uwaga

\section{Uwagi wprowadzające}

Herderowska koncepcja „wewnętrznego języka” nie doczekała się jeszcze należytego omówienia w dotychczasowej literaturze tematu, choć stanowi ona klucz

RAFAŁ MICHALSKI, doktor habilitowany, prof. UMK, Wydział Filozofii i Nauk Społecznych Uniwersytetu Mikołaja Kopernika w Toruniu; adres do korespondencji: Collegium Minus, Fosa Staromiejska 1A, 87-100 Toruń; e-mail: metasis@umk.pl 
do właściwego zrozumienia zarówno jego antropologii, jak i filozofii języka. Zanim przejdę do ekspozycji struktury wywodów zawartych w artykule, omówię kilka osobliwości Herderowskiej metody filozofowania i zarysuję najważniejsze obszary problemowe, które można wyodrębnić w jego teorii genezy ludzkiej mowy. To zaś pozwoli mi określić współrzędne omawianej koncepcji na mapie całości rozważań Herdera nad pochodzeniem języka.

Na początku warto podkreślić, że ożywiona recepcja filozofii języka Herdera rozpoczęła się dopiero w latach 80-tych ubiegłego wieku. Katalizatorem wzmożonego zainteresowania badaczy tym tematem było niewątpliwie krytyczne wydanie jego dzieł ${ }^{1}$. Systematyczna analiza twórczości autora Rozprawy o pochodzeniu języka (dalej Rozprawy) dokonana zarówno przez niemieckich, jak i anglojęzycznych filozofów i filologów, odsłoniła głębsze, a niekiedy zaskakująco współczesne aspekty refleksji Herdera nad naturą języka. Na potrzeby dalszych wywodów wskażę dwa z nich: antyredukcjonizm i zastosowanie myślenia koniekturalnego.

Po pierwsze, warto podkreślić, że nagminne uznawanie Herdera za prekursora filozoficznego linguistic turn, doszukujące się w jego myśleniu tezy, jakoby analiza języka stanowić miała klucz do rozwiązania wszystkich zagadnień filozoficznych, zniekształca obraną przez niego perspektywę badawczą. Herder zawsze ujmuje język w szerszym, niejęzykowym kontekście praktyki, poznania i zmysłowości. Wprawdzie pewne ustępy jego pism sugerują interpretację, że utożsamia on procesy myślowe z aktami mowy, jednak ustępy te odczytywane są w oderwaniu od reszty wywodów. Autor Rozprawy niewątpliwie uwypukla istotne znaczenie mowy dla procesu kształtowania się ludzkiego poznania, społeczeństwa i kultury, tym niemniej nie stawia między nimi znaku równości. Język nigdy nie wyznacza nieprzekraczalnych granic rozumienia, nie zamyka wspólnoty językowej w hermetycznym światoobrazie. W tym sensie, jak pokazuje Georg Bertram, należałoby raczej umieścić Herderowską filozofię języka w ramach filozoficznego post linguistic turn ${ }^{2}$.

Po drugie, nieredukcjonistyczny charakter teorii Herdera wiąże się ściśle ze stosowaną przez niego metodą, która nie była wcześniej wyraźnie rozpoznana

${ }^{1}$ Johann Gottfried Herder, Werke, 10 Bände, red. Martin Bollacher i in. (Frankfurt am Main: Deutscher Klassiker Verlag, 1985-2000).

${ }^{2}$ Georg Bertram, „Herders antireduktionische Sprachphilosophie”, w: Herder im Spiegel der Zeiten: Verwerfungen der Rezeptionsgeschichte und Chancen einer Relektüre, red. Tilman Borsche (München: Fink, 2006), 227. 
przez badaczy. To właśnie rzekomy brak refleksji metodologicznej stanowił stale powracający wątek krytyki jego projektu filozoficznego. Łączenie ustaleń nauk empirycznych z poetycką, figuratywną formą prezentacji oceniano - od czasów miażdżącej recenzji Myśli o filozofii dziejów autorstwa Kanta - jako przejaw nieuprawnionego mieszania różnych porządków językowych, który dyskwalifikuje poznawczą prawomocność głoszonych przez Herdera tez 3 .

Specyfikę teoretycznego dyskursu autora Rozprawy trafnie odzwierciedla pojęcie koniektury zaproponowane przez Thomasa Metzgera, który opisuje za jego pomocą paradygmat praktykowania nauki w filologii i biologii XVIII wieku, będący alternatywą dla dedukcyjno-empirycznej metody klasycznej fizyki i spekulatywnej metafizyki ${ }^{4}$. Koniektura (die Konjektur) oznacza najbardziej prawdopodobne przypuszczenie, hipotezę, która zmierza do odkrycia nowych, ogólnych prawidłowości ujawniających się w tekstach lub fenomenach natury. Koniekturalne myślenie wyróżnia interdyscyplinarność i poszukiwanie płodnych analogii $\mathrm{w}$ rozmaitych, nie zawsze powiązanych ze sobą dyskursach ${ }^{5}$. Z założenia przyjmuje ono zdystansowaną pozycję względem istniejących teorii, relatywizuje je, unikając jednocześnie perfekcjonistycznego roszczenia do uniwersalnej prawdy. Rezultaty koniekturalnego myślenia mają zawsze tymczasową ważność, podporządkowane są bowiem hermeneutyce prawdopodobieństwa. Koniekturalna teoria stanowi więc heurystyczną ars inveniendi, sztukę odsłaniania nowych horyzontów poznawczych opartą na eksperymentach myślowych i wyszukiwaniu analogii. Podstawowym kryterium jej ważności jest die Bequemheit - w znaczeniu stosowności, czy też teoretycznej i praktycznej użyteczności ${ }^{6}$. Dana teoria staje się stosowna wówczas, gdy operuje płodnymi poznawczo pojęciami, bogactwem kreatywnych skojarzeń, gdy łączy rozmaite dyskursy, kierując się zasadą ekonomii myślenia - poszukiwaniem możliwie najprostszych, najbardziej użytecznych konstrukcji teoretycznych dla osiągnięcia bieżących celów poznawczych. Metzger porównuje tę metodę do Pierce'owskiego wnioskowania abdukcyjnego ${ }^{7}$, które zaczyna od zbioru zaobserwowanych faktów, a następnie poszukuje najprostszego

\footnotetext{
${ }^{3}$ Immanuel Kant, Recenzje Myśli o filozofii dziejów, w: Immanuel Kant, Rozprawy z filozofii historii, tłum. Mirosław Żelazny i inni (Kęty: Antyk, 2005), 50-68.

${ }^{4}$ Stefan Metzger, Die Konjektur des Organismus. Wahrscheinlichkeitsdenken und Performanz im späten 18. Jahhundert (Münich: Fink, 2002), 128-137.

${ }^{5}$ Tamże, 19.

${ }^{6}$ Tamże, 142-146.

${ }^{7}$ Tamże, 135-137.
} 
i najbardziej prawdopodobnego ich wyjaśnienia bez pozytywnej weryfikacji konkluzji. Innymi słowy, abdukcja pozwala nam wyjaśnić coś, o czym mamy już wstępną wiedzę, umieszczając rozpoznane fakty w nowej perspektywie. Koniekturalna teoria oparta na abdukcji rezygnuje więc z rygorów ścisłości, ale pozostaje wierna duchowi sceptycznego common sense - zdrowego ludzkiego rozumu, którego celem jest rozwiązywanie palących problemów.

Koncepcja genezy języka Herdera jest teorią koniekturalną, a zatem przybiera postać konstelacji różnorodnych choć równorzędnych perspektyw badawczych. Zawarty w tym metodologicznym podejściu element spekulatywności oddala ją wprawdzie od scjentystycznego modelu uprawiania nauki, ale zbliża do klasycznej filozofii, dla której spekulatywna wyobraźnia zawsze stanowiła płodny wymiar refleksji ukazującej w zwierciadle ogólnych, choć nie zawsze ścisłych pojęć niewidziane wcześniej wymiary i cechy świata. Warto również dodać, że w metodzie tej znika zadekretowana później przez Diltheya zasadnicza różnica między eksplanacyjnym naukami, które obserwują i wyjaśniają naturę a naukami interpretacyjnymi, które usiłują zrozumieć sens ekspresji ludzkiego życia. Herder równie poważnie traktuje bowiem odniesienia do fizjologii, geografii, medycyny, jak i hermeneutyczne intuicje oparte na wczuciu, aby uniknąć w ten sposób przymusu, który mógłby wywrzeć z góry przyjęty system dedukcyjny, a priori określający zasady swojej prawomocności.

W swoich rozważaniach nad genezą języka filozof operuje wieloma koniekturalnymi teoriami. Zastosowanie różnorodnych perspektyw badawczych ma w istocie na celu odsłonięcie kolejnych wymiarów „źródła” języka. Niemieckie słowo Ursprung (źródło) pominięte w polskim przekładzie tytułu rozprawy można odczytać jako metaforę ukazującą dynamiczny i złożony (wieloprzyczynowy) proces wyłaniania się języka. Herder wyraźnie deklaruje, że początki ludzkiej mowy owiane są mgłą nieprzeniknioną dla ludzkiego poznania, dlatego też rezygnuje z próby tworzenia teorii glottogenetycznej sensu stricto.

Jak sugeruje Schmitz-Evans, Herderowską kategorię źródła można zinterpretować jako synonim pojęcia przejścia (Übergang) opisującego specyficzny stosunek do granicy (między językiem i nie-językiem, tym, co zwierzęce i tym, 
co ludzkie $)^{8}$. Źródło jako przejście nie oznacza tutaj absolutnego początku, przekroczenia granicy w znaczeniu linii demarkacyjnej. Odnosi się ono raczej do obszaru granicznego, stanu pośredniego między tym, co znane a tym, co pozostaje poza zakresem naszego poznania. Słowo Ursprung, zarówno w słownikowym znaczeniu „źródła”, jak i w literalnym znaczeniu „pra-skoku” (Ur-Sprung) sugeruje, że mówiąc o nim, zakładamy zawsze pewne czasowe i przestrzenne "przed” - coś, z czego wypływa „źródło” lub od czego odbija się „skok”. Źródło to zatem sfera przejścia od tego, co niepoznawalne i niewyrażalne do dziedziny dostępnej poznaniu. Można ją opisać co najwyżej za pomocą metafor, środków niepojęciowych, które w przybliżeniu i tylko pośrednio mogą unaocznić proces wyłaniania się tego, co znamy z tego, co jest niedostępne dla naszej wiedzy.

W kontekście teorii Herdera należałoby używać tego terminu w liczbie mnogiej, jak uczynił to Gaier, wyróżniając w Rozprawie siedem źródeł języka ${ }^{9}$. Z kolei za Metzgerem można powiązać kategorię Ursprung z pojęciem siły, które oddaje dynamiczny, procesualny charakter procesu wyłaniania się mowy. Herder używa koniektury siły do opisu biologicznych i psychicznych procesów. Rezygnuje przy tym ze statycznego modelu siły, wykorzystywanego wówczas przez mechanikę lub postarystotelesowską metafizykę substancji i akcydensów. Siły działające w danym systemie (biologicznym lub psychicznym) są, według niego, zawsze w pełni zaktualizowane. Zmiany w nim zachodzące nie polegają na stopniowym urzeczywistnianiu potencjału możliwości, lecz są skutkiem oddziaływania sił zewnętrznych. Dlatego można powiedzieć, że źródła języka pojmowane jako konstytutywne siły nie są ukierunkowane tylko na wytwarzanie finalnego efektu, nie znikają po wygenerowaniu mowy, lecz działają nieprzerwanie - tak długo jak długo język pozostaje w użyciu, określając dynamikę jego zmian i rozwoju.

Zamykając wstępne uwagi, przedstawię krótko mapę głównych obszarów badawczych związanych z problemem pochodzenia języka, które Herder omawia w Rozprawie.

${ }^{8}$ Monika Schmitz-Emans, Metaphern der Sprache - Sprache der Metaphern. Metaphorologische Überlegungen zu sprachphilosophieschen Texten Herders, w: Herders Rhetoriken im Kontext des 18. Jahrhunderts, red. Ralf Simon (Heidelberg: Synchron, 2012), 69-70.

${ }^{9}$ Ulrich Gaier, Herders Sprachphilosophie und Erkenntniskritik (Stuttgart: Frommann-Holzboog, 1988). 
1. Antropologiczne rozważania nad zwierzęcym ,językiem doznania” zdeterminowanym przez specyficzną dla danego gatunku strukturę instynktów oraz nad ludzką ekspresją uczuć.

2. Protofenomenologiczna, przeprowadzona $\mathrm{z}$ perspektywy pierwszoosobowej analiza „wewnętrznego języka” uznanego za differentia specifica ludzkiej mowy.

3. Opis transformacji wewnętrznego języka w mowę akustyczną.

4. Charakterystyka praw kulturowej ewolucji języka.

Omawiana w tym artykule koncepcja „wewnętrznej mowy”, czy też pierwszych „wewnętrznych słów”, należy do drugiego obszaru badawczego i stanowi ważny element całej konstrukcji teoretycznej, zazwyczaj ignorowany w literaturze tematu. Wewnętrzne słowo-cecha (innerliches Merkwort) powstaje za pośrednictwem zmysłowej autorefleksji, która zaczyna odnosić do siebie wyodrębnione i zakodowane wcześniej znaki sensoryczne. Nie jest to jeszcze język werbalny, artykułowany na zewnątrz, lecz milcząca rozmowa duszy z sobą samą ${ }^{10}$. Herder tylko pozornie nawiązuje tutaj do słynnej Platońskiej definicji myślenia, ponieważ opisywany przez niego wewnętrzny dialog rozgrywa się wyłącznie na płaszczyźnie zmysłowej wyobraźni, nie ma więc, jak u Platona, charakteru noetycznego. Już zwierzęta są zdolne do tworzenia znaków będących podporami dla pamięci, jednakże tylko człowiek potrafi używać ich do budowania złożonych konfiguracji, które otwierają przed nim przestrzeń wolności niespotykaną w świecie animalnym. Dlatego wokalna ekspresja pragnień i afektów nie może być traktowana jako faza wstępna języka. Teza otwierająca Rozprawę. „Już jako zwierzę człowiek posługuje się językiem”"11 odnosi się więc wyłącznie do „języka doznań”, a nie do specyficznie ludzkiego języka. Ten z kolei wyłania się dopiero wówczas, gdy zmysłowa uwaga nabiera charakteru intencjonalnego i towarzyszy jej samoświadomość.

Trzeci obszar badawczy, szeroko dyskutowany w literaturze tematu, czyli przejście do mowy wokalnej, nie będzie przedmiotem analiz tego artykułu. Zasygnalizuję jedynie, że większość dotychczasowych opracowań przechodzi do omó-

\footnotetext{
${ }^{10}$ Johann Gottfried Herder, Rozprawa o pochodzeniu języka, w: Johann Gottfried Herder, Wybór pism, tłum. Barbara Płaczkowska (Wrocław: Zakład Narodowy im. Ossolińskich, 1987), 98.

${ }^{11}$ Tamże, 60.
} 
wienia tego stadium, pomijając fazę wewnętrznego języka, co nieuchronnie zniekształca interpretację całości teorii Herdera. Czwarty, najlepiej opracowany obszar badawczy, tj. kulturowa ewolucja języka będzie punktem odniesienia moich analiz tylko w tych punktach, które wymagają uwzględnienia szerszego kontekstu interpretacyjnego. Będzie to istotne zwłaszcza tam, gdzie wyłączna koncentracja na monologicznym charakterze wewnętrznego języka mogłaby skłaniać do błędnego pojmowania go jako solipsystycznego procesu.

Najważniejszym elementem mojej interpretacji będzie rozróżnienie dwóch aspektów poznawczej funkcji ludzkiego umysłu, którą Herder wprowadza w miejsce klasycznego pojęcia intelektu (Verstand) ${ }^{12}$. Filozof od samego początku swojej twórczości przeciwstawia się pokartezjańskiemu dualizmowi poznania pojęciowego i zmysłowego. Zdolność myślenia i rozróżniania nie jest dla niego odrębną władzą, która porządkuje surowy materiał wrażeń dostarczany przez zmysły, lecz stanowi integralną część aparatu sensorycznego ${ }^{13}$. Wprawdzie w późniejszym okresie, zwłaszcza w Metakrytyce ${ }^{14}$, sam posługuje się pojęciem intelektu, lecz czyni to ze względów polemicznych, chcąc dostosować swój aparat pojęciowy do terminologii Kantowskiej. Na etapie Rozprawystosuje natomiast dwa pojęcia, które opisują poznawczą funkcję umysłu ucieleśnionego w zmysłowości: Besonnenheit (identyfikująca uwaga): termin odnoszący się do procesu kodowania znaków ikonicznych oraz Besinnung (refleksyjna uwaga): termin odnoszący się do funkcji rozróżniającej i syntetyzującej cechy utrwalone przez Besonnenheit, której towarzyszy autorefleksja ${ }^{15}$. Obydwie funkcje poznawcze odpowiadają za wyłonienie się „wewnętrznego", niewerbalnego języka.

Artykuł składa się z dwóch części, w pierwszej zrekonstruuję pojęcie zmysłowej uwagi, która kompensuje wrodzony człowiekowi deficyt instynktów i wyodrębnia w strumieniu doznań znaki pamięciowe; natomiast w drugiej, najważniejszej części, skupię się na analizie wewnętrznego języka ukonstytuowanego za pośrednictwem refleksyjnej uwagi.

${ }^{12}$ Rozróżnienie obydwu funkcji uwagi uwzględniają następujący autorzy: Frederick M. Barnard, Ilit Ferber. Ulrich Gaier. Por. bibliografię.

${ }^{13}$ Herder, Rozprawa, 85.

${ }^{14}$ Johann Gottfried Herder, Eine Metakritik zur Kritik der reinen Vernunft, w: Johann Gottfried Herder, Werke, Bd. 8, Schriften zu Literatur und Philosophie 1792-1800, red. Hans D. Irmscher (Frankfurt am Main: Deutscher Klassiker Verlag, 1998).

${ }^{15}$ Autor polskiego przekładu Rozprawy tłumaczy die Besonnenheit jako rozwagę, a Besinnung jako namysł. 
I.

\section{Besonnenheit - sensoryczny protojęzyk}

Herderowska teoria genezy języka czerpie z brytyjskiego empiryzmu (Locke), przejmując od niego tezę, że podłoże naszej wiedzy zakorzenione jest w zmysłowości. Oddala ją jednak od tej tradycji koncentracja na nieświadomym aspekcie procesu poznania i nacisk położony na jego zależności od języka, w czym z kolei przejawia się wpływ sensualistycznej filozofii Condillaca ${ }^{16}$. Poznanie dyskursywne nie jest oddzielną, autonomiczną władzą umysłu, lecz przejawia się w zalążkowej postaci już na poziomie percepcji zmysłowej. Jej najgłębsza warstwa, poprzedzająca poziom operacji konceptualnych, konstytuuje obszar poznania ciemnego, który Herder za Baumgartenem określa jako fundus animae - podstawę duszy ${ }^{17}$.

$\mathrm{Na}$ tym poziomie życia psychicznego wyłaniają się pierwsze wyobrażenia i zaczątki pamięci. Jest to obszar niejasnych, choć żywych, nasyconych afektami obrazów zmysłowych, które stanowią ukryte jądro świadomej aktywności człowieka. „Całą podstawę naszej duszy wypełniają ciemne idee, najżywsze i najliczniejsze, stłoczona masa, z której dusza sporządza swoje bardziej subtelne pojęcia; te ciemne idee są najpotężniejszymi sprężynami naszego życia, największym wkładem do naszego szczęścia i nieszczęścia"18. Najważniejszym celem procesów psychowitalnych zachodzących w fundus animae jest „zdrowie i szczęście w życiu”19 - stan równowagi psychofizycznej.

Ten przedjęzykowy wymiar psychiki wypełniają obrazy, a właściwie protobrazy, które płynnie łączą się ze sobą lub spontanicznie przyjmują inną postać. Wyobrażenia pochodzące z różnych modalności zmysłowych stapiają się ze sobą

\footnotetext{
${ }^{16}$ Por. Étienne Bonnot de Condillac, O pochodzeniu poznania ludzkiego, tłum. Kazimierz Brończyk (Warszawa: De Agostini \& Altaya, 2002), 141-231.

${ }^{17}$ W swojej Metafizyce Baumgarten definiuje ją następująco: „Dusza zawiera wiele niejasnych przedstawień. Wpisuje się to w coś, co nazywa się podstawą duszy (fundus animae)”. Aleksander Gottlieb Baumgarten, Metafizyka, tłum. Jacek Surzyn (Kęty: Wydawnictwo Marek Derewiecki, 2012), 179.

${ }^{18}$ Johann Gottfried Herder, Viertes Kritisches Wäldchen, w: Johann Gottfried Herder, Werke, Bd. 4, Schriften zu Philosophie, Literatur, Kunst und Altertum 1774-1787, red. Martin Bollacher i in. (Frankfurt am Main: Deutscher Klassiker Verlag, 1994), 273.

${ }^{19}$ Johann Gottfried Herder, Erkennen und Empfinden der menschlichen Seele, w: Johann Gottfried Herder, Werke, Bd. 4, 334.
} 
za pośrednictwem synestetycznych transpozycji. Obrazy wizualne są transponowane na obrazy akustyczne, taktylne i vice versa. „Wzrok zapożycza wrażenia od dotyku i wierzy, że widzi coś, co w istocie tylko czuje. Wzrok i słuch wzajemne się odszyfrowują. Zmysł powonienia wydaje się duchem smaku lub przynajmniej jego młodszym bratem. $Z$ tego wszystkiego dusza tka sobie szatę, swoje zmysłowe uniwersum" 20 . W podstawie duszy działają zatem rozmaite procesy synestetycznej translacji oparte na zasadzie „podobieństwa zmysłów w ich źródle”21 odpowiadającej za metaforyczne "przenoszenie z jednego uczucia do drugiego" ${ }^{22}$. Procesy te bez udziału zmysłowej uwagi tworzą „spontaniczny język”, który nie daje się wyrazić w języku werbalnym, ponieważ „to, co daje się odczuć w niejasnym uczuciu [...] nie jest zdolne do żadnej wyraźnej cechy"23.

Według Herdera, nie można utrzymywać, że ludzka mowa pochodzi od jakiejś odrębnej władzy umysłu, która aktualizowałaby się w pewnej fazie rozwoju i wtórnie tworzyła system fonetyczny. Język od samego początku zakorzeniony jest w naturze ludzkiej zmysłowości ${ }^{24}$. Jego wstępne stadium, nazwijmy je protojęzkiem, polega na kodowaniu sensorycznych doznań za pośrednictwem funkcji zmysłowej uwagi (Besonnenheit) wyróżniającej człowieka na tle świata fauny. Uwaga uwalnia aparat zmysłowy od przemożnego nacisku popędów i instynktownych reakcji. Kompensuje ona brak sztywnego mechanizmu selekcyjnego, który u zwierząt dzieli pobudzenia na wymagające niezwłocznej reakcji i bodźce całkowicie obojętne. „U człowieka widocznie według innego prawa natury następują idee: zmysłowa uwaga panuje nawet w najbardziej zmysłowym stanie, tylko jest mniej widoczna. Najbardziej nieświadome stworzenie, przychodząc na świat, staje się od razu uczniem natury, w sposób odmienny od zwierzęcia"25.

Herder przyznaje, że również animalna wyobraźnia może dysponować mętnymi i jasnymi przedstawieniami, jednak nigdy nie wytwarza ona wyraźnych reprezentacji ${ }^{26}$. Zmysłowa uwaga człowieka tworzy natomiast dystans wobec napływających wrażeń, dzięki któremu człowiek „potrafi skoncentrować się na jednej

\footnotetext{
20 Tamże, 349.

${ }^{21}$ Herder, Rozprawa, 116.

22 Tamże, 117.

23 Tamże, 139.

${ }^{24}$ Tamże, 85.

25 Tamże, 137.

26 Tamże, 136.
} 
chwili czuwania, zatrzymać się dobrowolnie na jednym obrazie, rozumnie i spokojnie zająć się nim i wysegregować cechy wskazujące, że jest to jeden przedmiot”27. Za pośrednictwem funkcji zmysłowej uwagi aparat poznawczy uczy się kontroli nad doznaniami oraz kreowania i organizowania przedpojęciowych wyobrażeń (idei w terminologii Herdera). Dzięki niej dochodzi do wyodrębnienia istotnych dla organizmu doznań jako charakterystycznych cech, czy dystynktywnych znaków będących punktami oparcia dla pamięci. Jak podkreśla filozof, uwaga reaguje przede wszystkim na najsilniejsze, najbardziej żywe wrażenia, które wnikają najgłębiej i najwyraźniej w duszę ${ }^{28}$. Uruchamiany przez nią proces stopniowej semiotyzacji zmysłowości zastępuje zatem instynktowne mechanizmy selekcji. „Gdyby człowiek miał zmysły zwierząt, nie miałby rozumu; właśnie bowiem zbytnia pobudliwość jego zmysłów, właśnie tak silnie przez nie napierające wyobrażenia musiałyby zdławić wszelka zimną uwagę"29. Chłód ludzkiej uwagi nie oznacza obojętności kalkulującego intelektu, neutralnej postawy wolnej od czynników afektywnych i doraźnych potrzeb organizmu. Besonnenheit jest bowiem „panowaniem nad wszystkimi siłami w tym głównym kierunku, które będzie jego przeznaczeniem zarówno w pierwszym momencie, jak i w ostatnim"30. Obecne w podstawie duszy wyobrażenia, doznania i afekty funkcjonują jako siły, które dążą do zamanifestowania się w polu cielesnej ekspresji i działania. Besonnenheit nadaje kierunek tym dążeniom już w najwcześniejszej fazie rozwoju, kiedy zmysły dziecka nie są jeszcze ukształtowane. „Uwaga musi ujawnić się w pierwszych myślach dziecka, jak u owada to, że jest owadem”31. Herder przedstawia jej działanie na przykładzie owcy, która dla głodnego wilka jest źródłem pokarmu, a dla barana przedmiotem pożądania ${ }^{32}$. Jedynie człowiek uwolniony od nacisku popędów potrafi uchwycić cechę (dźwięk beczenia) jako neutralny znak rozpoznawczy. Wbrew pozorom przykład ten nie wskazuje na bezinteresowność ludzkiej uwagi. Besonneheit zdefiniowana jako ukierunkowanie wszystkich sił, afektów, dążeń działających w duszy stanowi poniekąd ich wypadkową, albo syntezę scalającą w jednym punkcie nieokreślone motywacje. Człowiek potencjalnie

\footnotetext{
${ }^{27}$ Tamże, 87.

${ }^{28}$ Tamże, 88.

${ }^{29}$ Tamże, 83.

${ }^{30}$ Tamże, 85.

${ }^{31}$ Tamże.

${ }^{32}$ Tamże, 88-89.
} 
może wykorzystać zwierzę jako pokarm, jako materiał lub w jakikolwiek inny sposób. Brak niezawodnych instynktów implikuje niezdeterminowanie jego dążeń, a tym samym wytwarza przestrzeń wolności, która rzutuje również na sposób postrzegania owcy. Uwaga poszukuje wyrazistej cechy, która samoczynnie wybija się na pierwszy plan i służyć ma w pierwszym rzędzie nie tyle zaspokojeniu jakiejś przypadkowej potrzeby, lecz identyfikacji obiektu. Herder neguje istnienie apriorycznych struktur transcendentalnej podmiotowości porządkującej chaos zmysłowej materii. Scalanie wielości wrażeń w jedność przedstawienia zachodzi już na poziomie zmysłowości.

Siłą napędową tego procesu wstępnej symbolizacji płynnych wyobrażeń sensorycznych jest zmysł wewnętrzny, sensorium commune, syntetyzujący za pośrednictwem uwagi wielość obrazów w jedną charakterystyczną cechę, czy pieczęć (Gepräge) świadomości.

Wszystkie przedmioty naszych zmysłów stają się nasze tylko dzięki temu, że jest spostrzegamy, tzn. oznaczamy je mnie lub bardziej jasno i żywo pieczęcią naszej świadomości. Zyskuję orientację w gąszczu zmysłowych przedmiotów, który mnie otacza i zdobywam panowanie nad chaosem napierających na mnie doznań przez to, że oddzielam jedne przedmioty od innych, że nadaję im zarys, miarę i postać, a tym samym tworzę sobie jedność w tym, co różnorodne i oznaczam ją żywo i wiarygodnie pieczęcią mojego wewnętrznego zmysłu, jak gdyby zmysł ten był pieczęcią prawdy ${ }^{33}$.

Wyodrębnianie i kodowanie charakterystycznych znaków różnych modalności zmysłowych przyczynia się do rozwoju nie tylko zmysłowości, ale również wyobraźni i pamięci. Ponieważ na tym poziomie nie działa jeszcze refleksyjna samoświadomość (Besinnung), która tworzy „wewnętrzne słowa” oraz temporalną ciągłość między nimi, protojęzykowa wyobraźnia ma charakter topograficzny ${ }^{34}$. Obrazy dryfujące w podstawie duszy tworzą dość swobodne połączenia asocjacyjne, nieuporządkowane według chronologii czasowej, a scalane jedynie przez zmysłową uwagę, która nadaje kierunek afektywnym dążeniom.

Jak pisze Herder, Besonnenheit wydobywa z „oceanu doznań, który szumem przenika wszelkie zmysły”35 wyspowe obrazy, które zostają odciśnięte „pieczęcią”

\footnotetext{
${ }^{33}$ Johann Gottfried Herder, Über Bild, Dichtung und Fabel, w: Herder, Werke, Bd. 4, 635.

${ }^{34}$ Herder, Eine Metakritik, 352.

${ }^{35}$ Herder, Rozprawa, 87.
} 
świadomości. W procesie metaschematyzacji ${ }^{36}$ uczestniczą wszystkie zmysły, ale dominuje słuch i wzrok. Symultanicznie postrzegane obiekty wzorku są metaschematyzowane na potrzeby wewnętrznego zmysłu w przestrzennie uporządkowane przedstawienia, natomiast rejestrowane jako następstwo wrażenia akustyczne tworzą zaczątek świadomości czasu, budują pierwsze chronologiczne powiązania. Akustyczny i optyczny metaschematyzm konkurują ze sobą i jednocześnie kooperują, wytwarzając połączenia w procesie nieustannej habituacji.

Topografia wyobraźni kształtowanej przez Besonnenheit odzwierciedla zarazem „krąg życia”, w którym rozwija się człowiek. Herder przyznaje bowiem, że zmysłowa uwaga może zostać ukierunkowana z zewnątrz, np. przez rodziców, którzy, jakbyśmy dzisiaj powiedzieli, tworzą scenę wspólnej uwagi. Ralf Simon dowodzi, że nie można jej analizować w izolacji od społecznych i kulturowych praw rządzących rozwojem języka ${ }^{37}$. Dążenia tkwiące w podstawie duszy jednostkowej są więc pośrednio ukształtowane przez interakcje $z$ najbliższym otoczeniem. To z kolei potwierdza interpretację, że „zimna uwaga” uwolniona od przymusu bezpośredniej reakcji i natychmiastowej gratyfikacji nie zajmuje pozycji niezaangażowanego obserwatora, jak mogłoby sugerować literalne odczytanie tekstu Herdera. Wymaga ona bowiem ćwiczenia i habituacji: „Stan naszej chłodnej uwagi (Besonnenheit) jest sztucznym stanem, który osiągamy stopniowo poprzez doświadczenie, naukę i przyzwyczajenie, a który często trudno nam utrzymać w nieoczekiwanych okolicznościach" ${ }^{\text {38 }}$.

Nawet wówczas, gdy uwaga ulega zewnętrznym wpływom, to ostatecznie sam podmiot musi utworzyć prototypową cechę obiektu, która w najgłębszej warstwie wyobraźni będzie (za pośrednictwem Besinnung) przyciagać niczym magnez inne powiązane z nią cechy. Dlatego „pieczęć świadomości” jest zazwyczaj niepowtarzalna. Sama Besonnenheit nie tworzy jeszcze wewnętrznego języka, lecz zmysłowo-imaginatywny protojęzyk, który jest niestabilny i silnie zindywidualizowany. Możemy powiedzieć, że zmysłowa uwaga stawia jedynie znaki przestankowe w niezrozumiałym tekście obrazów lub że rozkłada w szumie doznań akcenty, które tworzą melodię będącą podłożem dla pamięci i późniejszego języka. Owa melodia jest niepowtarzalna u każdego człowieka.

${ }^{36}$ Pojęcie metaschematyzmu oznacza u Herdera proces schematyzacji wstępnie ustrukturyzowanych doznań sensorycznych w trwałe wyobrażenia, które mogą stać się obiektem pamięci.

${ }^{37}$ Ralf Simon, Der poetische Text als Bildkritik(Paderborn: Fink, 2009), 144-146.

${ }^{38}$ Herder, Über Bild, 643. 
II.

Besinnung - zmysłowa samoświadomość

W literaturze tematu zazwyczaj nie uwzględnia się Herderowskiego rózróżnienia na uwagę identyfikującą i refleksyjną. Wielu badaczy wręcz utożsamia obydwa pojęcia lub uznaje, że rozróżnienie to jest niejasne i pozbawione znaczenia. Uważna lektura Rozprawy pokazuje jednak, że Herder dość precyzyjnie wyodrębnia obydwie funkcje uwagi zmysłowej. Przede wszystkim podkreśla, że identyfikująca uwaga jest warunkiem uwagi refleksyjnej i że ta relacja nie jest odwracalna. „Nie każda aktywność duszy jest bezpośrednim następstwem refleksji (Besinnung), każda jednakże jest następstwem uwagi" ${ }^{39}$. Besonneheit konstytuuje zatem zmysłowo-imaginacyjny protojęzyk izolowanych cech, które stanowią podłoże dla operacji Besinnung tworzącej właściwy „wewnętrzny język”. Zmysłowa uwaga działa punktowo i ma pasywny charakter, pozbawiona jest bowiem autorefleksji, która umożliwia kreatywne wykorzystanie utrwalonych znaków sensorycznych. Herder podkreśla to wyraźnie, pisząc, że ludzka dusza jest „osadzona w stanie zmysłowej uwagi” („in Zustand von Besonnenheit gesetzt”) ${ }^{40}$. Trudny do przełożenia na język polski imiesłów „gesetzt” podkreśla wyraźnie bierny charakter funkcjonowania identyfikującej uwagi, a pośrednio odnosi się do pojęcia Setzung (ustanowienie), które oznacza akt ukonstytuowania rozpoznawalnej cechy. Sama Besonnenheit nie jest jeszcze aktywną syntezą w sensie samoświadomego aktu ustanowienia, lecz receptywną identyfikacją. W przytoczonym wcześniej przykładzie owcy zmysłowa uwaga jedynie wyodrębnia cechę charakterystyczną (dźwięk beczenia). Dopiero ponowna percepcja owcy umożliwia rozpoznanie tej cechy przez Besinnung. Cecha ta przekształca się wówczas w pierwsze wewnętrzne słowo, które umysł będzie mógł potem przywołać niezależnie od zewnętrznych okoliczności.

Owca wraca [...] beczy - i teraz [zmysł wewnętrzny duszy] ją rozpoznaje! „Aha! Ty beczysz!” czuje wewnętrznie, rozpoznał ją w sposób ludzki, gdyż wyraźnie, to znaczy poprzez cechę rozpoznaje i nazywa. [...] Przez cechę? I cóż było to innego, jak

${ }^{39}$ Herder, Rozprawa, 138.

${ }^{40}$ Johann Gottfried Herder, Abhandlung über den Ursprung der Sprache, w: Johann Gottfried Herder, Werke, Bd. 1, Frühe Schriften 1764-1772, red. Ulrich Gaier (Frankfurt am Main: Deutscher Klassiker Verlag, 1985), 722. W polskim przekładzie ustęp ten znajduje się w: Herder, Rozprawa, 87. 
nie wewnętrzne słowo-cecha? Dźwięk beczenia dostrzeżony przez człowieka jako znamię owcy, siłą tego określenia, stał się nazwą owcy, chociaż jego język nigdy nie próbował jej wyjąkać ${ }^{41}$.

Z powodu powierzchownej lektury tego fragmentu interpretowano Herderowską koncepcję genezy języka jako prostą teorię mimetyczną, która wyjaśnia początki języka w oparciu o zjawiska onomatopei ${ }^{42}$. Nic bardziej mylnego, gdyż Herder stwierdza expressis verbis: „Nie ma w duszy zasady naśladownictwa”" Przyczyną mylnej interpretacji wydaje się być akustyczna specyfika wykorzystanego przez Herdera przykładu. Bez wątpienia pojawia się tutaj pewien rodzaj mimetyczności, ale wykraczający daleko poza imitatywne reakcje. Należy pamiętać, że „dźwięczące słowo" ${ }^{44}$ nie oznacza wyartykułowanego dźwięku, nie jest skierowane na zewnątrz ku jakiemuś adresatowi, lecz rozbrzmiewa wyłącznie w duszy:

Rozpoznał owcę po beczeniu, był to uchwycony znak, dzięki któremu dusza wyraźnie uprzytomniała sobie wyraźnie określoną idę - czymże jest innym jak nie słowem? A czym jest cały ludzki język, jak nie zbiorem takich słów? Nawet jeśliby nigdy się nie zdarzyło, żeby tę ideę przekazać innemu stworzeniu i tym samym chcieć lub móc oddać beczeniem ustami tę cechę refleksyjnej uwagi (Besinnung); jego dusza jakby we wnętrzu zabeczała, ponieważ wybrała ten dźwięk na znak przypomnie$\mathrm{nia}^{45}$.

Powyższy cytat zawiera w skrócie sedno koncepcji wewnętrznego języka. Dźwięk beczenia staje się "nazwą”, jednakże nie w znaczeniu kategorii syntaktycznej, lecz jako niewyartykułowane, wewnętrzne słowo-cecha. Z kolei termin „idea” można rozumieć jako konotację nazwy, czyli jako ogół innych cech, które są powiązane z jej desygnatem (wełnistość owcy, jej postać, zapach, jakości dotykowe etc.). Dźwięk beczenia funkcjonuje zatem jako akustyczny rdzeń, wokół którego krystalizuje się semantyczny potencjał (konotacja nazwy) odnoszący się do owcy.

Przykład z owcą może sugerować, że Herder promuje mimetyczną teorię genezy języka, ponieważ powstanie wewnętrznego słowa zakłada podobieństwo

${ }^{41}$ Herder, Rozprawa, 89.

${ }^{42}$ Manfred Krüger, „Der menschlich-göttliche Ursprung der Sprache. Bemerkungen zu Herders Sprachphilosophie", Wirkendes Wort 1967, nr 17: 7.

${ }^{43}$ Herder, Rozprawa, 90.

${ }^{44}$ Tamże, 99.

${ }^{45}$ Tamże, 89 . 
między utrwalonym przez uwagę akustycznym obrazem a dźwiękiem wydawanym przez realną owcę. Ponadto autor Rozprawy przyznaje zmysłowi słuchu prymat w procesie kształtowania się języka. Należy jednak pamiętać, że Besinnung nie ogranicza się do sfery dźwiękowej, lecz działa również w innych modalnościach zmysłowych, co Herder podkreśla w dalszej części tekstu.

Narodziny języka nie są dla niego rezultatem imitacji, nie istnieje naturalna motywacja wewnętrznych słów poza nielicznymi wyrazami dźwiękonaśladowczymi. Wbrew pozorom przykład z owcą nie mieści się w kategorii onomatopei, gdyż „nazwa” nie ma tutaj charakteru wokalnego. To wyłącznie bezgłośny ślad pamięciowy, który służy do porządkowania rozmaitych wyobrażeń, afektów i doznań odsyłających do tego samego desygnatu. Kategorię podobieństwa należałoby więc odnieść do refleksyjnej struktury Besinnung lub efektu echa, o którym trafnie pisze Ilit Ferber:

\begin{abstract}
Manifestacja echa [...] jest niezależna od mowy lub produkcji dźwięku, dlatego powinna być rozumiana raczej w kategoriach repetycji, zgody i czegoś, co jest zwrotnie odzwierciedlane. Echo dotyczy więc w większym stopniu refleksyjnego ruchu w obrębie zamkniętej przestrzeni duszy, aniżeli tylko prostego powtórzenia dźwięku. To Herderowskie źródło ludzkiego języka odnosi się do efektu echa, który występuje w trzech zmysłach (słuchu, wzroku i dotyku) ${ }^{46}$.
\end{abstract}

Uwaga ta jest niezwykle cenna dla moich analiz. Według Ferber echa nie należy utożsamiać ani $\mathrm{z}$ naśladowaniem zewnętrznego dźwięku, ani z prostym mechanicznym powtórzeniem. Efekt echa charakteryzuje bowiem przede wszystkim refleksyjność Besinnung, która odzwierciedla samą siebie. Jak pisze Herder, dzięki refleksyjnej uwadze człowiek „może wyszukać sobie zwierciadlaną sferę, może przejrzeć się w sobie jak w zwierciadle"47. Jak należy to rozumieć? W akcie Besinnung poprzez jednoczesną apercepcję świata i podmiotu powstaje specyficzna struktura uznania (Anerkennung), która łączy rozpoznanie danej cechy z aktem „porozumienia duszy z sobą samą"48. Uwaga przeprowadza tutaj wewnętrzny dia-

${ }^{46}$ Ilit Ferber, Langage Pangs. On Pain and the Origin of Language (New York: Oxford University Press, 2019), 69.

${ }^{47}$ Herder, Rozprawa, 82. Herder, Abhandlung, 717.

${ }^{48}$ Tamże, 90. 
log, który wieńczy uznanie danej cechy za wewnętrzne słowo. Herderowi nie chodzi bynajmniej o solipsystyczne monologizowanie, jak sugeruje Küntzel ${ }^{49}$, ponieważ każdy język, również wewnętrzny, charakteryzuje się, według niego, społeczną naturą. „Zgodnie więc ze swoją naturą pierwsza myśl ludzka przygotowuje do umiejętności prowadzenia dialogu z drugimi. Pierwsza cecha, którą ujmuję, jest słowem-cechą dla mnie i słowem-wiadomością (Mitteilungswort) dla innych"50. Wewnętrzny język służy przede wszystkim do scalania i porządkowania fundus animae i spełniając tę funkcję przygotowuje umysł do rozwinięcia zdolności komunikacyjnych. Bezgłośne słowa nie tworzą właściwego intersubiektywnego języka, ale są jego warunkiem koniecznym, nawet jeśli ich społeczna natura ma wyłącznie wirtualny charakter.

Włączenie w akt refleksyjnej uwagi struktury uznania pozwala Herderowi odrzucić tezę o arbitralności ludzkiej mowy. „Wymyślić z głowy język dowolnie i bez jakiegokolwiek uzasadnienia wyboru jest dla duszy ludzkiej, która we wszystkim pragnie mieć choćby jedno jedyne uzasadnienie, co najmniej taką męczarnią, jak dla ciała pozwolić się zagłaskać na śmierć" ${ }^{11}$ Uznanie nie może być interpretowane jako czysto subiektywna, arbitralna decyzja, ponieważ zależy ono od uprzedniego aktu Besonnenheit, a zatem od praw rządzących ludzką zmysłowością. Narodziny wewnętrznego słowa opierają się zatem na paradoksalnej umowie, która nie jest ani konwencją zawieraną przez społeczność, ani wyłącznie subiektywnym i arbitralnym aktem.

Herder usiłuje ominąć tutaj błędne koło, w jakie popadają kontraktualistyczne teorie genezy języka zakładające, że członkowie danej wspólnoty pozbawieni języka mogą umówić się, jakie dźwięki należy uznać za akceptowalne przez wszystkich słowa. Skoro ludzkie myślenie zależy od języka, powyższa teoria popada w ewidentną sprzeczność „Najmniej jest to porozumienie, dowolna, konwencja społeczna" ${ }^{2}$.

${ }^{49}$ Heinrich Küntzel, Johann Gottfried Herder zwischen Riga und Bückeburg. Die Ästhetik und Sprachphilosophie der Frühzeit nach ihren existenziellen Motiven (Frankfurt am Main: Diesterweg, 1936), 69.

\footnotetext{
${ }^{50}$ Herder, Rozprawa, 98.

${ }^{51}$ Tamże, 108.

${ }^{52}$ Tamże, 90.
} 
Również teorie wywodzące język z gestów nie rozwiązują tego problemu, ponieważ nie potrafią przekonująco wyjaśnić przejścia od ekspresji cielesnej do intencjonalnej mowy. Filozof akceptuje przekonanie, że konwencja społeczna jest niezbędna do uformowania dojrzałego języka, docenia również wagę mowy ciała jako zjawiska towarzyszącego i wspierającego proces kształtowania się ludzkiej komunikacji. Broni jednak idei, zgodnie z którą konwencja jako akt uznania musi zostać najpierw ustanowiona w obrębie jednostkowej podmiotowości: „Rodzice nigdy nie uczą dzieci języka bez tego, żeby one same zawsze go nie wymyśliły, rodzice zwracają im tylko uwagę na różnice przedmiotów przy pomocy różnych znaków słownych i tak nie zastępują im, lecz ułatwiają i wynagradzają użycie rozumu przez język" ${ }^{\prime 3}$.

Podsumowując powyższe analizy, warto jeszcze raz uwypuklić różnicę między identyfikującą i refleksyjną funkcją zmysłowej uwagi. Besinnung tworzy wewnętrzne słowo-cechę, które różni się od cechy wyodrębnionej przez Besonnenheit swoją wyrazistością i stabilnością. ${ }^{54} \mathrm{~W}$ obu przypadkach powstają konfiguracje obrazów pamięciowych zogniskowane wokół wyróżnionego symbolu zmysłowego. Jednakże aktywna, refleksyjna uwaga tworzy je wolicjonalnie, a ponadto zaczyna je odnosić nawzajem do siebie, rozbudowując coraz gęstszą sieć powiązań. W ten sposób symbole nie odnoszą się tylko do zewnętrznego obiektu, lecz również komunikują się między sobą, dzięki czemu mogą reprezentować obiekt in absentia. Refleksyjna uwaga aktywizuje wreszcie samoświadomość, która jest podstawą procesów myślowych. Natomiast Besonnenheit to pasywny akt identyfikacji wyodrębnionej cechy, który niejako automatycznie uruchamia niestabilne połączenia skojarzeniowe.

Pojęcie „wewnętrznego słowa-cechy” wyjaśnione na przykładzie z owcą może być mylące pod względem terminologicznym, ponieważ sugeruje, że Herderowi chodzi w tym przypadku o językowe signifiant - akustyczny obraz słowa. W istocie należałoby je rozumieć jako signifié - prejęzykowe znaczenie złożone ze zmysłowo-imaginatywnych treści. Jako dźwięczący w duszy symbol jednoczy

${ }^{53}$ Tamże, 92.

${ }^{54}$ Herder nawiązuje tutaj do Baumgartenowskiego rozróżnienia, zgodnie z którym percepcje mętne (confusis) nie są wprawdzie wyraźne (distinctivus), ale przysługuje im pewien stopień jasności (claritas). Mętne wyobrażenia, czyli cechy wyodrębnione przez Besonneheit ukazują przedmiot wyłącznie w oparciu o świadectwo zmysłów. Besinnung przekształca zaś cechy w wewnętrzne słowa-cechy, które są wyraźne w tym sensie, że mogą stanowić podstawę dla pojęciową dystynkcji. 
ono całą konfigurację innych mniej lub bardziej wyraźnych wyobrażeń odnoszących się do tego samego obiektu, wprowadzając tym samym strutkury porządku w obszarze fundus animae.

\section{Zakończenie}

\section{U źródeł poetyckiego geniuszu}

Herder opisuje pierwszy moment Besinnung jako przebudzenie $\mathrm{z}$ imaginatywno-zmysłowego snu równoznaczne $\mathrm{z}$ powstaniem języka ${ }^{55}$. Z perspektywy samoświadomości wszelkie stany zachodzące w podstawie duszy, nawet te, które są wyodrębniane przez Besonneheit snują „mętny sen wyobrażeń, który może niejako podążać jedynie za wegetatywym uczuciem; ale w tym ciemnym śnie działa dusza mocą wszystkich swoich sił" ${ }^{56}$. Jednakże „stopniowo dusza budzi się ze swojej drzemki i przez całe życie będzie nosić w sobie te wcześnie uchwycone senne idee, będzie ich używać i w pewnym sensie będzie się z nich składać" ${ }^{57}$. Autorefleksyjna uwaga budząca życie psychiczne do stanu samoświadomości przekształca cechy sensoryczne w wewnętrze słowa, rozbudowując stopniowo sieci wyobrażeniowych asocjacji. W ten sposób konstytuuje się niepowtarzalny potencjał semantyczny, który nigdy nie zostaje w pełni wyartykułowany w języku. Krystalizujące się wokół wewnętrznych słów-cech, nasycone emocjami połączenia skojarzeniowe stanowią źródło poetyckiego geniuszu, z którego czerpie każdy kreatywny akt ludzkiej mowy. W „otchłani duszy” spoczywają zatem niedostępne dla racjonalnego poznania konstelacje obrazów i "jedynie resztki tych obrazów"58 mają szansę dotrzeć do świadomości. Jak pisze filozof, tworzą one „pierwsze, potężne, wieczne formy pamięci i fantazji”"59. Formacje psychiczne powstające w późniejszych stadiach rozwoju języka niejako nawarstwiają się na nich, tracąc jednocześnie bezpośrednią łączność z nimi. Jednakże nawet wówczas stłumione pokłady zmysłowego znaczenia zabarwiają świadome przeżycia i językową ekspresję. Wzrost poziomu abstrakcyjności języka tożsamy z oddalaniem się od jego zmysłowego podłoża nie eliminuje więc bezpowrotnie pierwszych „wewnętrznych

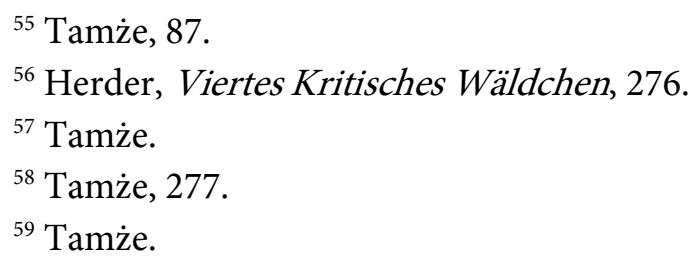


słów”: „Stanowią one ciemne podłoże w nas, które później wyblakłe obrazy i kolory naszej duszy zbyt często i zbyt mocno modyfikują i jedynie szkicują"60.

W rzadkich chwilach, gdy „dogłębnie zamieszkujemy w sobie”61 i pozwalamy tym obrazom przedostać się na powierzchnię świadomości, racjonalne Ja napotyka swojego ciemnego sobowtóra i „przeżywa wstrząs u samych podstaw, wycofuje się, jakby stanęło nad przepaścią lub jak gdyby zobaczyło swój obraz"62. Te momenty rozbłysku ukrytego potencjału semantycznego konstytuują moment „pełnej mowy”, w której odtworzona zostaje elastyczność skojarzeniowych połączeń między zmysłowymi wyobrażeniami. Mówiący podmiot przełamuje wówczas reguły konwencjonalnej mowy podporządkowanej społecznym normom komunikacji i zaczyna wyrażać swoje najgłębsze odczucie świata i siebie samego.

Wewnętrzny język wyłania się zatem z nieustannego dialogu między zmysłowymi symbolami, afektami i mętnymi wyobrażeniami, który zachodzi w podstawie duszy i odzwierciedla wpływy zewnętrznego świata. Język ten jest dogłębnie zanurzony w strumieniu doświadczenia, które nie może zaistnieć bez pośrednictwa biologicznego organizmu zaabsorbowanego swoim otoczeniem. Wyraża on jednak nie tylko witalne potrzeby ciała, ale również źródłowe formy postrzegania i odczuwania świata. Tym samym niewypowiedziany język wewnętrznych słów definiuje granicę między obszarem stanów mentalnych, które są bezpośrednio dostępne dla ujęzykowionej świadomości a sferą nieświadomych znaczeń, które dochodzą do głosu w przypływach poetyckiego geniuszu.

\section{Bibliografia}

Barnard, Frederick. Zwischen Aufklärung und politischer Romantik. Eine Studie über Herders soziologisch-politisches Denken. Berlin: Erich Schmidt Verlag, 1964.

Baumgarten, Aleksander Gottlieb. Metafizyka. Tłum. Jacek Surzyn. Kęty: Wydawnictwo Marek Derewiecki, 2012.

Bertram, Georg. Herders antireduktionische Sprachphilosophie. W: Herder im Spiegel der Zeiten: Verwerfungen der Rezeptionsgeschichte und Chancen einer Relektüre, red. Tilman Borsche, 227-246. München: Fink, 2006.

\footnotetext{
${ }^{60}$ Tamże, 278.

${ }^{61}$ Tamże, 277.

${ }^{62}$ Tamże, 276.
} 
Ferber, Ilit. Langage Pangs. On Pain and the Origin of Language. New York: Oxford University Press, 2019.

Gaier, Ulrich. Herders Sprachphilosophie und Erkenntniskritik. Stuttgart: Frommann-Holzboog, 1988.

Herder, Johann Gottfried. Myśli o filozofii dziejów, t. 1-2. Tłum. Józef Gałecki. Warszawa: PWN, 1962.

Herder, Johann Gottfried. Abhandlung über den Ursprung der Sprache. W: Johann Gottfried Herder. Werke, Bd. 1, Frühe Schriften 1764-1772, red. Ulrich Gaier, 695-810. Frankfurt am Main: Deutscher Klassiker Verlag, 1985.

Herder, Johann Gottfried. Rozprawa o pochodzeniu jezzyka. W: Johann Gottfried Herder. Wybór pism. Tłum. Barbara Płaczkowska, 59-175. Wrocław: Zakład Narodowy im. Ossolińskich, 1987.

Herder, Johann Gottfried. Erkennen und Empfinden der menschlichen Seele. W: Johann Gottfried Herder. Werke, Bd. 4, Schriften zu Philosophie, Literatur, Kunst und Altertum 17741787, red. Martin Bollacher i inni, 187-243. Frankfurt am Main: Deutscher Klassiker Verlag, 1994.

de Condillac, Étienne Bonnot. O pochodzeniu poznania ludzkiego. Tłum. Kazimierz Brończyk. Warszawa: De Agostini \& Altaya, 2002.

Herder, Johann Gottfried. Viertes Kritisches Wäldchen. W: Johann Gottfried Herder. Werke, Bd. 4, 247-442.

Herder, Johann Gottfried. Über Bild, Dichtung und Fabel. W: Johann Gottfried Herder, Werke, Bd. 4, 633-677.

Herder, Johann Gottfried. Eine Metakritik zur Kritik der reinen Vernunft. W: Johann Gottfried Herder. Werke, Bd. 8, Schriften zu Literatur und Philosophie 1792-1800, red. Hans D. Irmscher, 303-640. Frankfurt am Main: Deutscher Klassiker Verlag, 1998.

Kant, Immanuel. Recenzje Myśli o filozofii dziejów. W: Imamnuel Kant. Rozprawy z filozofii historii. Tłum. Mirosław Żelazny i inni, 50-68. Kęty: Antyk, 2005.

Krüger, Manfred. „Der menschlich-göttliche Ursprung der Sprache. Bemerkungen zu Herders Sprachphilosophie". Wirkendes Wort 1967, nr 17: 1-11.

Küntzel, Heinrich. Johann Gottfried Herder zwischen Riga und Bückeburg. Die Ästhetik und Sprachphilosophie der Frühzeit nach ihren existenziellen Motiven. Frankfurt am Main: Diesterweg, 1936.

Metzger, Stefan. Die Konjektur des Organismus. Wahrscheinlichkeitsdenken und Performanz im späten 18. Jahhundert. Münich: Fink, 2002.

Schmitz-Emans, Monika. Metaphern der Sprache - Sprache der Metaphern. Metaphorologische Überlegungen zu sprachphilosophieschen Texten Herders. W: Herders Rhetoriken im Kontext des 18. Jahrhunderts, red. Ralf Simon, 67-80. Heidelberg: Synchron, 2012.

Simon, Ralf. Der poetische Text als Bildkritik. Paderborn: Fink, 2009. 


\section{Summary}

\section{The Conjecture of the "Internal Language" in Johann Gottfried Herder' philosophy}

The author examines the concept of non-verbal speech of "inner words" which lies at the core of Herder's theory of language genesis. The topic is generally ignored by scholars dealing with the subject. The major point in the author's interpretation is that of distinguishing two aspects of the cognitive function of the mind embodied in sensuality introduced by Herder in place of the classic concept of the intellect. This is the distinction between Besonnenheit (identifying attention) which encodes iconic signs at the ground of the soul (fundus animae), and Besinnung (reflective attention) which transforms the signs fixed by Besonnenheit into inner words. Identifying attention compensates for the inborn human deficit of instincts, while reflective attention introduces the element of self-reflection into sensuality and generates an internal dialogue of the soul with itself, based on which the first thought processes and phonetic language arise.

Keywords: language, Johann Gottfried Herder, sensory cognition, imagination, fundus animae, identifying attention, reflective attention

\section{Zusammenfassung}

\section{Die Konjektur der inneren Sprache in der Philosophie von Johann Gottfried Herder}

Der Artikel beschreibt das Konzept der nonverbalen Sprache der "inneren Wörter", die ein wichtiges Element von Herders Theorie des Sprachursprungs ausmacht und leider von Forschern meistens übersehen wird. Der wichtigste Punkt der vorgestellten Interpretation wird die Unterscheidung zwischen zwei Aspekten der kognitiven Funktion des Geistes sein, die in der Sinnlichkeit verkörpert sind und die Herder anstelle des klassischen Konzepts des Verstandes einführt: die Besonnenheit (identifizierende Aufmerksamkeit), die ikonische Zeichen in der Grundlage der Seele (fundus animae) kodiert und die Besinnung (reflektierende Aufmerksamkeit), die die von Besonnenheit geprägten Zeichen in innere Worte verwandelt. Die Besonnenheit kompensiert das angeborene menschliche Instinktdefizit, während die Besinnung eine Funktion der Selbstreflexion in die Sinnlichkeit einführt und einen inneren Dialog der Seele mit sich selbst konstituiert, auf dessen Grundlage die ersten Denkprozesse und die phonetische Sprache entstehen. 
Schlüsselwörter: Sprache, Johann Gottfried Herder, sinnliche Erkenntnis, Vorstellungskraft, Fundus Animae, Besonnenheit, Besinnung

Information about Author:

RAFAŁ MICHALSKI, habilitated doctor, associate professor, Faculty of Philosophy and Social Sciences, Nicolaus Copernicus University in Toruń; address for correspondence: Collegium Minus, Fosa Staromiejska 1A, 87-100 Toruń; e-mail: metasis@umk.pl 